Sing, Stranger 


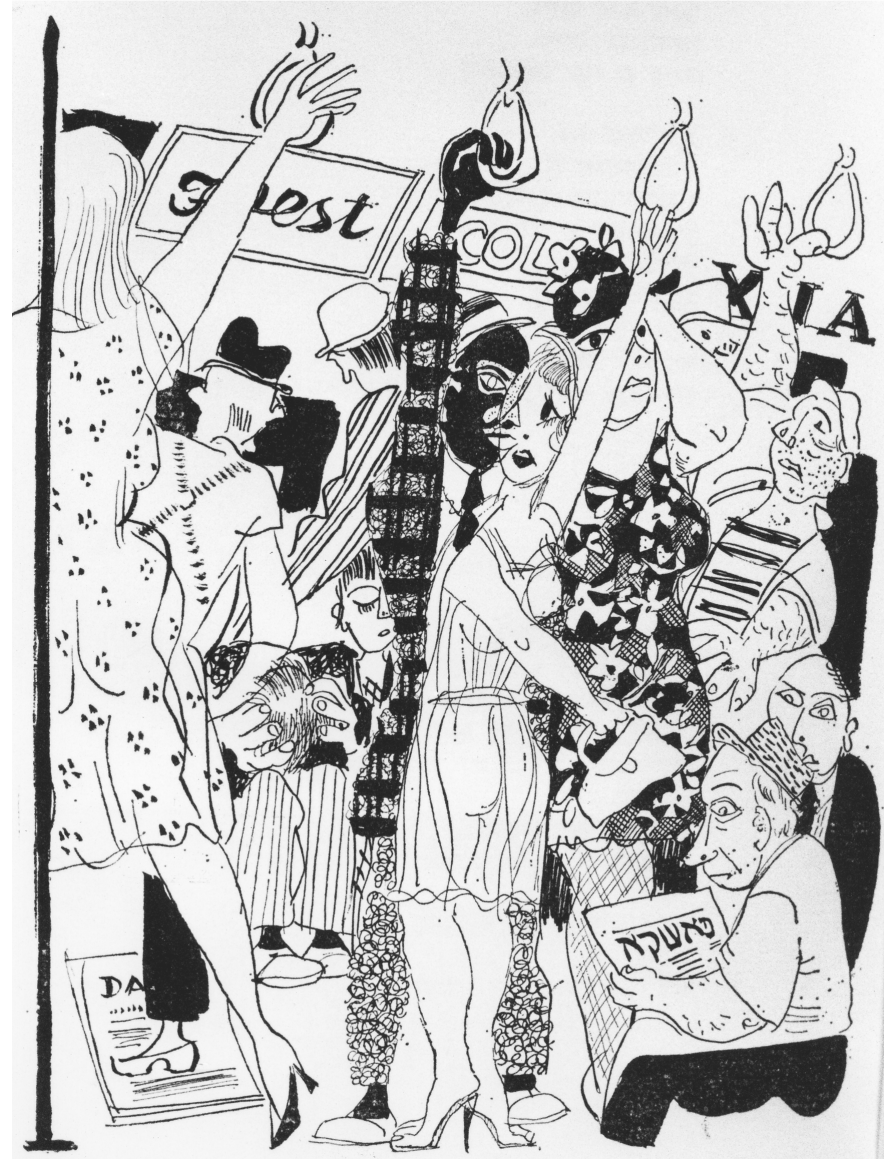

Illustration to A. Léyeles's poem "In the Subway" by Yosef Foshko 


\section{Sing, Stranger}

\section{A Century of American Yiddish Poetry}

A Historical Anthology

\section{Edited by Benjamin Harshav}

Translated by Benjamin Harshav and Barbara Harshav 
Stanford University Press

Stanford, California

(2006 by Benjamin Harshav and Barbara Harshav. All rights reserved.

No part of this book may be reproduced or transmitted in any form or by any means, electronic or mechanical, including photocopying and recording, or in any information storage or retrieval system without the prior written permission of Stanford University Press.

Printed in the United States of America on acid-free, archival-quality paper

Library of Congress Cataloging-in-Publication Data

Sing, stranger : a century of American Yiddish poetry--a historical anthology / edited by Benjamin Harshav ; translated by Benjamin Harshav and Barbara Harshav.

p. cm.

ISBN-I 3: 978-0-8047-5 $183-4$ (cloth : alk. paper)

ISBN-10: ०-8047-5 I 83-8 (cloth : alk. paper)

I. Yiddish poetry--United States--Translations into English. 2. Yiddish poetry--United States. 3. Authors, Yiddish--United States--Biography. I. Harshav, Benjamin, I928- II. Harshav, Barbara, 1940-

$\mathrm{PJ}_{5}$ I9I.E $3 \mathrm{~S}_{5} 62006$

$839^{\prime}$.I I $3080973^{--\mathrm{dc} 22}$

2006024109

Designed by Bruce Lundquist

Typeset at Stanford University Press in Io/I 4 Sabon 